Article

\title{
Experimental Investigations of Physical and Chemical Properties for Microalgae HTL Bio-Crude Using a Large Batch Reactor
}

\author{
Farhad M. Hossain ${ }^{1,2, *}$, Jana Kosinkova ${ }^{1,2}$, Richard J. Brown ${ }^{1,2}$, Zoran Ristovski ${ }^{1,2}$, \\ Ben Hankamer ${ }^{3}$, Evan Stephens ${ }^{3}$ and Thomas J. Rainey ${ }^{1,2, *}$ \\ 1 Biofuel Engine Research Facility, Queensland University of Technology (QUT), Brisbane, QLD 4001, \\ Australia; jana.adamovska@hdr.qut.edu.au (J.K.); richard.brown@qut.edu.au (R.J.B.); \\ z.ristovski@qut.edu.au (Z.R.) \\ 2 International Laboratory for Air Quality and Health, Queensland University of Technology (QUT), Brisbane, \\ QLD 4001, Australia \\ 3 The Institute for Molecular Bioscience, University of Queensland, 306 Carmody Road, St. Lucia, QLD 4072, \\ Australia; b.hankamer@imb.uq.edu.au (B.H.); e.stephens@imb.uq.edu.au (E.S.) \\ * Correspondence: mfarhad03@yahoo.com (F.M.H.); t.rainey@qut.edu.au (T.J.R.); Tel.: +61-3138-1977 (T.J.R.)
}

Academic Editor: Thomas E. Amidon

Received: 21 December 2016; Accepted: 28 March 2017; Published: 5 April 2017

\begin{abstract}
As a biofuel feedstock, microalgae has good scalability and potential to supply a significant proportion of world energy compared to most types of biofuel feedstock. Hydrothermal liquefaction (HTL) is well-suited to wet biomass (such as microalgae) as it greatly reduces the energy requirements associated with dewatering and drying. This article presents experimental analyses of chemical and physical properties of bio-crude oil produced via HTL using a high growth-rate microalga Scenedesmus sp. in a large batch reactor. The overarching goal was to investigate the suitability of microalgae HTL bio-crude produced in a large batch reactor for direct application in marine diesel engines. To this end we characterized the chemical and physical properties of the bio-crudes produced. HTL literature mostly reports work using very small batch reactors which are preferred by researchers, so there are few experimental and parametric measurements for bio-crude physical properties, such as viscosity and density. In the course of this study, a difference between traditionally calculated values and measured values was noted. In the parametric study, the bio-crude viscosity was significantly closer to regular diesel and biodiesel standards than transesterified (FAME) microalgae biodiesel. Under optimised conditions, HTL bio-crude's high density $\left(0.97-1.04 \mathrm{~kg} \cdot \mathrm{L}^{-1}\right)$ and its high viscosity $\left(70.77-73.89 \mathrm{~mm}^{2} \cdot \mathrm{s}^{-1}\right)$ had enough similarity to marine heavy fuels. although the measured higher heating value, $\mathrm{HHV}$, was lower $\left(29.8 \mathrm{MJ} \cdot \mathrm{kg}^{-1}\right)$. The reaction temperature was explored in the range $280-350{ }^{\circ} \mathrm{C}$ and bio-crude oil yield and $\mathrm{HHV}$ reached their maxima at the highest temperature. Slurry concentration was explored between $15 \%$ and $30 \%$ at this temperature and the best HHV, O:C, and $\mathrm{N}: \mathrm{C}$ were found to occur at $25 \%$. Two solvents (dichloromethane and $n$-hexane) were used to recover the bio-crude oil, affecting the yield and chemical composition of the bio-crude.
\end{abstract}

Keywords: microalgae; hydrothermal liquefaction (HTL); bio-crude; fatty acid methyl esters (FAME); fuel properties

\section{Introduction}

Microalgae are of considerable interest for the production of next-generation biofuels $[1,2]$ that are indistinguishable from petroleum fuels based on their properties [3]. This is because using microalgae for biofuel production would have fewer adverse effects on food supply and other agriculture $[4,5]$ as 
they can be cultivated on non-arable land using fresh, waste, or saline water sources and enable more efficient nutrient recycling and achieve higher productivities [6,7].

A range of conversion techniques are under development to generate biofuels from microalgae. These include solvent extraction followed by trans-esterification to produce fatty acid methyl esters (FAME), fermentation to alcohols, as well as thermochemical conversion pathways, such as pyrolysis and hydrothermal liquefaction (HTL) [8,9], to produce bio-crude oils. HTL efficiently converts wet microalgae biomass feedstock into bio-crude oil [10-12] as it eliminates the need for expensive pre-drying of the raw material. Compared to trans-esterifying lipids obtained from microalgae by solvent extraction, HTL has the potential to require less energy for the conversion process which would improve production costs [13]. The high solvent losses associated with FAME production means its financial viability is directly related to the lipid content (high lipid content being better) whereas HTL can make use of more highly productive microalgae species (i.e., more tonnes per hectare) which have higher carbohydrate content, lower lipid content and the potential for additional co-products [14]. These advantages of HTL make it a competitive route for the conversion of raw microalgae biomass to fuels [10-12].

HTL converts microalgae biomass into bio-crude oil, as well as aqueous, gas, and solid phase products at elevated pressures (5-24 MPa) and moderate temperatures $\left(250-400{ }^{\circ} \mathrm{C}\right)[15,16]$. A wide range of microalgae biomass feedstocks has been explored using HTL, including laboratory and commercially grown strains Botryococcus braunii [17], Arthrospira (Spirulina), Scenedesmus sp. [18], and Tetraselmis sp. [2]. Among the green microalgae the most common Scenedesmus sp. has high productivity although the lipid yield can be optimised to reach over $60 \%$ [19], which makes this strain attractive for biofuel production. In general, the variation in the biochemical composition, particularly the carbon chain length and the degree of saturation, affects the conversion rate and the chemical-physical properties of the HTL bio-crude [20,21].

The effect of operating conditions such as residence time, temperature, slurry concentration, and catalyst, on physical and chemical properties of microalgae HTL bio-crude have been investigated previously in limited studies [22-25]. In this study, three temperatures and slurry concentrations were investigated in the range $280-350{ }^{\circ} \mathrm{C}$ and $15-30 \%$, respectively; temperature and concentration, as well as reaction time of $60 \mathrm{~min}$ was based loosely on the literature [10,23]. Higher temperatures were not explored so as to remain below water's supercritical point. Jena et al. [23] demonstrated that among the various process parameters the temperature had the strongest influence on the higher heating value (HHV), viscosity and chemical composition. HTL produces bio-crude oil that, by weight, can have 6-8 times higher oxygen and nitrogen content than heavy fuel oil (HFO) [26]. The inorganic salts in many types of HTL bio-crude oil require modifications to be compatible with a traditional refining process $[2,10,27,28]$. Bio-crude oil may also need subsequent upgrading to improve quality and reduce these undesired components.

Most experimental research in HTL continues to use small batch reactors (less than $1000 \mathrm{~mL}$ ), while scale-up reactors are usually continuous. The kinetics of small size reactors or autoclaves may differ from large ones, both batch and continuous, which lead to different chemical reactions. Therefore, the results from these reactors are not fully reliable in terms of scale-up. Batch reactors are commonly used to validate the process conditions for further commercial scale. Although industry tends to prefer continuous reactors to batch reactors because of higher energy efficiency, the steady production rate and uniformity of product, large batch reactors still have several key advantages [29]:

- Pumping the biomass slurry into a continuous reactor at high pressure and temperature remains a technological challenge at the industrial scale;

- Ability to easily switch between feedstocks; and

- For a factory, individual reactors can be taken out-of-service for maintenance.

Due to the lack of bio-crude for testing, most groups only reported values at optimised parameters. The aim of this study was to conduct more comprehensive experimental analyses with three key 
objectives: (i) to empirically investigate the relationship between the reaction parameters and experimentally determined values physical properties of bio-crude; (ii) to evaluate how the chemical composition varies with operating conditions; and (iii) to identify the best possible fuel physical and chemical properties of microalgae HTL bio-crude. Both physical and chemical properties are needed to meet legislated diesel and FAME biodiesel standards. In further analysis, the physical properties of the best bio-crude were compared with other fuel standards to determine the similarities and reveal areas for improvement.

\section{Materials and Methods}

\subsection{Hydrothermal Liquefaction (HTL)}

The experiments were performed in a $1.8 \mathrm{~L}$ batch reactor system (Parr Instruments Co., Moline, IL, USA) and data were collected across three physical variables: temperature, slurry concentration, and solvents for recovering the bio-crude from the liquid mixture. The experimental temperatures used were $280{ }^{\circ} \mathrm{C}, 300{ }^{\circ} \mathrm{C}$, and $350{ }^{\circ} \mathrm{C}$, and solid concentrations in the slurry were $15 \%, 25 \%$, and $30 \%$ by weight. When loading the reactor, the headspace was purged thoroughly using nitrogen to remove oxygen, and pre-pressurised to 2 bar with nitrogen gas. The reactor was heated to the desired temperature (heating rate $\sim 3.3{ }^{\circ} \mathrm{C} / \mathrm{min}$ ) and held constant for one hour which is consistent with the literature [23,30-34]. At the end of the reaction time, the reactor was cooled by passing water through an internal cooling tube until room temperature was reached. Experiments were performed in duplicate and the average yield of two runs is reported.

After the gas was vented from the reactor, the vessel was opened and the mixture was separated (following the steps in Figure 1). The walls of the reactor were washed thoroughly with solvent (dichloromethane or $n$-hexane) and mixed with the liquid phase. The amount of solvent added was determined as the volume of the solvent per mass dry weight of algae. The solid phase was removed from the liquid mixture by vacuum filtration before being washed with the remaining solvent. The solids were then oven-dried at $105^{\circ} \mathrm{C}$ overnight.

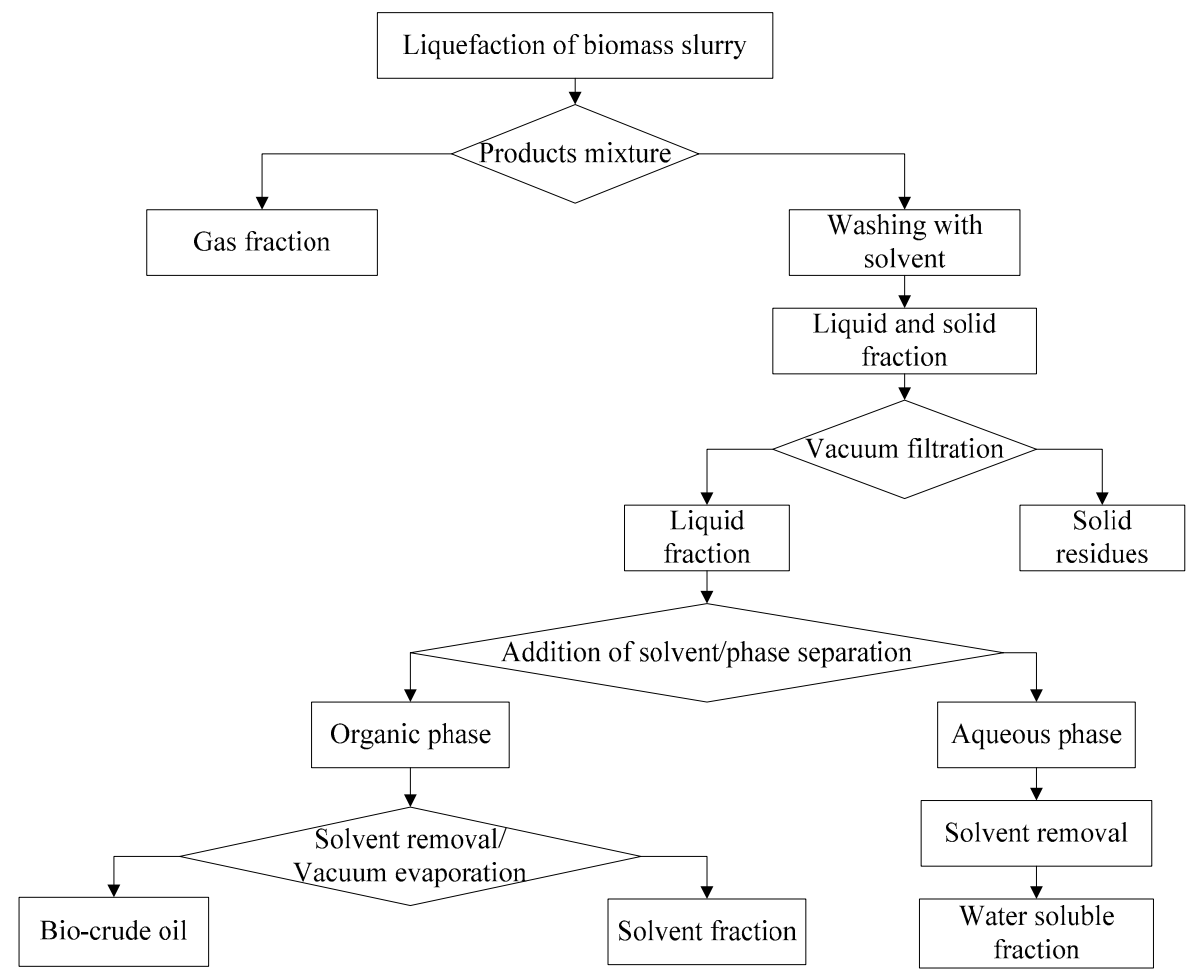

Figure 1. Hydrothermal liquefaction (HTL) product recovery workflow. 
The liquid phase mixture was poured into a separation funnel and the water-insoluble components separated (organic phase) were separated from the water soluble (aqueous) phase. The solvent was evaporated from the bio-crude by a rotary vacuum evaporator. Due to the volatile nature of dichloromethane (DCM) we have used $40{ }^{\circ} \mathrm{C}$ (760 Tor) and placed an additional trap between the vacuum source and the condenser unit, whereas for $n$-hexane the temperature was set at $68^{\circ} \mathrm{C}(760$ Tor). The evaporation was continued until no further yield was obtained. The time for the DCM was shorter than that for $n$-hexane.

\subsection{Raw Materials}

A robust and fast growing green freshwater microalga Scenedesmus sp. which had been isolated as part of previous work [35] was used for these experiments. The Scenedesmus sp. bulk biomass was produced at the University of Queensland's Solar Biofuels Research Centre facility at Pinjarra Hills near Brisbane, Australia. High density slurry was frozen and stored at $-20{ }^{\circ} \mathrm{C}$, directly after harvest to prevent degradation during the course of the HTL experiments. Proximate analyses were performed according to American Society for Testing and Materials (ASTM) standards and using a thermo-gravimetric analyzer (TGA-NETZSCH thermal analyser, NETZSCH Australia Pty Ltd., New South Wales, Australia). Ultimate analyses were carried out using a LECO TruSpec Micro CHNS elemental analyser (LECO Corporation, Saint Joseph, MI, USA) (Table 1). The HHV of the dried microalgae sample was calculated according to the formula used by Demirbas [36] and Friedl [37], which were $18.07 \mathrm{MJ} \cdot \mathrm{kg}^{-1}$ and $19.5 \mathrm{MJ} \cdot \mathrm{kg}^{-1}$, respectively, for Scenedesmus species microalgae. The lipid content for the samples used in this study was typically $15-20 \%$.

Table 1. Microalgae proximate and ultimate analyses data.

\begin{tabular}{cccc}
\hline \multicolumn{2}{c}{ Proximate Analyses } & \multicolumn{2}{c}{ Ultimate Analyses } \\
\hline Composition & Percentage of Weight & Element & Percentage of Weight \\
\hline Fixed carbon & 24.8 & $\mathrm{C}$ & 46.3 \\
Volatile matter & 67.3 & $\mathrm{H}$ & 6.9 \\
Ash & 3.2 & $\mathrm{O}$ & 32.3 \\
Moisture & 85 & $\mathrm{~N}$ & 7.3 \\
- & - & $\mathrm{S}$ & 2.3 \\
\hline
\end{tabular}

\subsection{Analytical Methods}

The conversion and product yields were defined as the mass fraction of the respective product (i.e., bio-crude and solid residue) as a function of the initial mass of biomass. For approximation, the total yield of gas + aqueous products were determined by difference according to the approach commonly used in the literature (e.g., [38]).

$$
\begin{gathered}
\text { Solid residues }(\text { wt. } \%)=\left(\frac{\text { mass of solid residues }}{\text { mass of raw material }}\right) \times 100 \% \\
\text { Bio }- \text { crude yield }(\text { wt. } \%)=\left(\frac{\text { mass of bio }- \text { crude }}{\text { mass of raw material }}\right) \times 100 \%
\end{gathered}
$$

\subsection{Bio-Crude Properties Measurements}

The chemical and physical bio-crude properties such as HHV, viscosity, density, and chemical composition were measured experimentally. HHV of the bio-crude was measured with a Parr 6200 compensated jacket calorimeter (Moline, IL, USA). For comparative purposes, the correlations which are used for fossil fuels (liquid, gas and coal) form the basis of calculation applied in other research articles. Boie's and Dulong's formulae are shown Equations (3) and (4), respectively [36,39]. 


$$
\begin{gathered}
\operatorname{HHV}(\mathrm{MJ} / \mathrm{kg})=35.16 \mathrm{C}+116.225 \mathrm{H}-10.09 \mathrm{O}+6.28 \mathrm{~N}+10.465 \mathrm{~S} \\
\operatorname{HHV}(\mathrm{MJ} / \mathrm{kg})=0.3383 \mathrm{C}+1.422(\mathrm{H}-\mathrm{O} / 8)
\end{gathered}
$$

A Brookfield DV-III ultra-programmable rheometer (Brookfield engineering laboratories, Inc., Middleboro, MA, USA) was used to measure the viscosity of the bio-crude at constant temperature. The accuracy of the rheometer for viscosity measurements is $\pm 1.0 \%$ of full scale range for a specific spindle running at a specific speed. The density of the bio-crude was measured using German industrial standard (DIN) 1306.

Gas chromatography with mass spectroscopy (GC-MS) was used to identify the chemical compositions in the bio-crude samples. GC-MS analyses were performed using a Thermoscientific, Trace 1310 system (Thermo Scientific ${ }^{\mathrm{TM}}$, Milan, Italy), equipped with a single quadrupole mass selective detector (ISQ). Each sample was dissolved and diluted in dichloromethane. The injector was set to $250{ }^{\circ} \mathrm{C}$ and a Thermo TG-5MS ( $30 \mathrm{~m}$ long, $0.25 \mathrm{~mm}$ ID, $0.25 \mathrm{~mm}$ film) column was used. The oven was programmed at an initial temperature at $50{ }^{\circ} \mathrm{C}$ (held $1 / \mathrm{min}$ ) then heated at a constant rate of $10^{\circ} \mathrm{C} \cdot \mathrm{min}^{-1}$ until a temperature of $250{ }^{\circ} \mathrm{C}$ was reached, and then held for $9 \mathrm{~min}$ with a split ratio of 1:25 and a column flow of $1.4 \mathrm{~mL} \cdot \mathrm{min}^{-1}$. The MS detector scanned from 40 to $400 \mathrm{~m} / \mathrm{z}$ with a solvent cut time of $1.8 \mathrm{~min}$ and the ion source and transfer line temps were both set at $250{ }^{\circ} \mathrm{C}$. The carrier mode was set to constant flow.

\section{Results and Discussion}

To investigate the influence of reaction conditions on product yields, HTL was conducted using a range of reaction temperatures, solid concentrations, and two types of solvents (dichloromethane and $n$-hexane) to recover the bio-crude.

\subsection{Influence of Solvents in Product Separation}

After completion of HTL, the bio-crude must be separated from the aqueous and solid phases. The most common solvents reported in the literature, with a focus on maximising bio-crude yield are the organic solvents dichloromethane, chloroform, acetone, and $n$-hexane [34,40]. However, there was insufficient information about the effect of these polar and non-polar solvents on the bio-crude quality. The data presented in Figure 2 was obtained from experimental runs with $25 \%$ slurry concentration at $350{ }^{\circ} \mathrm{C}$ for $60 \mathrm{~min}$ in a nitrogen atmosphere.

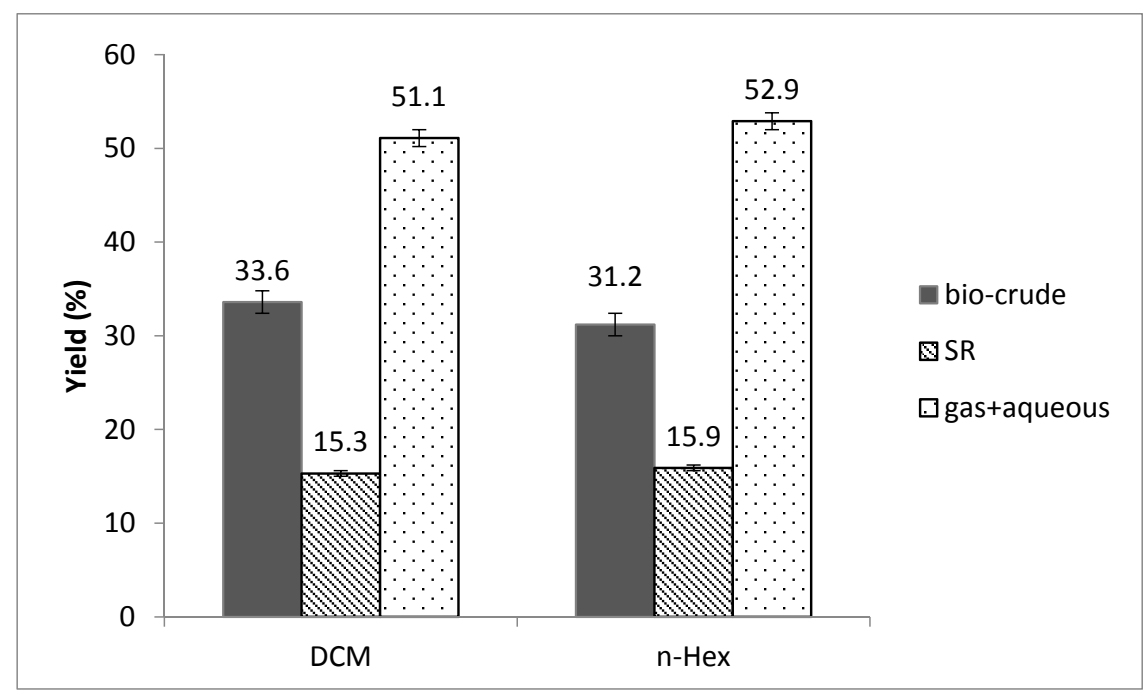

Figure 2. Effect of solvent on the recovery of bio-crude, solids and gas + aqueous components after HTL treatment $\left(350^{\circ} \mathrm{C}, 60 \mathrm{~min}, 25 \%\right.$ slurry concentration). 
Suitable nonpolar ( $n$-hexane) and more polar (dichloromethane; DCM) solvents were selected based on previous studies and the product yields and chemical composition were compared (see Section 3.4). For the same algae species, and under identical reaction conditions, bio-crude yield varied from $31.2 \%(\mathrm{wt}$ ) with $n$-hexane to $33.6 \%(\mathrm{wt})$ with DCM. This differed from the results of Valdez et al. [34] who obtained the highest bio-crude yield (39\%) with nonpolar solvents (hexadecane and decane) and the lowest value with $30 \%$ DCM for Nannochloropsis sp. at $350{ }^{\circ} \mathrm{C}$ for $60 \mathrm{~min}$. This supports the view that both biomass properties and the solvent type used for separating products after HTL has an influence on bio-crude recovery. However, as $n$-hexane has a higher boiling point than DCM, this could lead to higher losses of volatile compounds during the evaporation process and this could possibly account for the small difference (2.4\%). Despite this, DCM was used as a solvent of choice for product separation in all subsequent experiments.

\subsection{Effect of Reaction Temperature on Yield and HHV}

The effect of three different temperatures $\left(280^{\circ} \mathrm{C}, 300^{\circ} \mathrm{C}, 350^{\circ} \mathrm{C}\right)$ was investigated using a $60 \mathrm{~min}$ reaction time and a nitrogen atmosphere at an initial pressure of 2 bar (Figure 3). Bio-crude yield increased with temperature from $24.5 \%$ at $280{ }^{\circ} \mathrm{C}$ to $32.5 \%$ at $300{ }^{\circ} \mathrm{C}$, and reached a maximum of $33.6 \%$ at $350{ }^{\circ} \mathrm{C}$, in the range analysed. Similar results for temperature's influence on bio-crude yield have been reported recently $[23,32,41]$. The HHV was characterized for bio-crude generated at temperatures of $300{ }^{\circ} \mathrm{C}$ and $350{ }^{\circ} \mathrm{C}$ only, due to an insufficient amount of bio-crude at $280^{\circ} \mathrm{C}$. The HHV followed the trend of bio-crude yield; it increased from $26.1 \mathrm{MJ} \cdot \mathrm{kg}^{-1}$ to $29.8 \mathrm{MJ} \cdot \mathrm{kg}^{-1}$, which was approximately $50 \%$ higher than in the original microalgae biomass. The solid residue yield decreased gradually from $20.1 \%$ to $15.3 \%$ with rising temperature suggesting organic conversion mostly into the aqueous and gas phases. These outcomes generally support processing at the higher temperature range where bio-crude yield was maximized. Higher temperatures than these were not investigated because of potential corrosion issues related to supercritical fluids. To this end, $350{ }^{\circ} \mathrm{C}$ was used for future experiments.

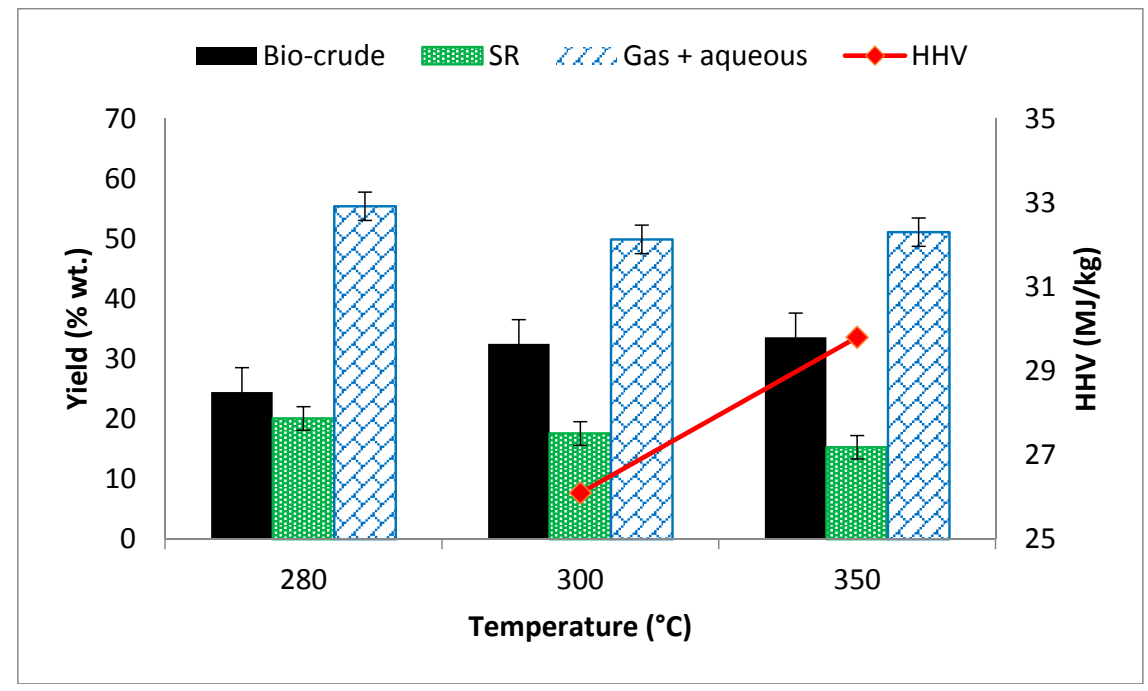

Figure 3. Influence of the reaction temperature on products yields at $25 \%$ solids concentration and $60 \mathrm{~min}$ reaction time in nitrogen atmosphere ( 2 bar at commencement). Values are for yield data.

\subsection{Effects of Solid Concentration on Yield and HHV}

Liquefaction of Scenedesmus sp. was conducted at $350{ }^{\circ} \mathrm{C}$ for $60 \mathrm{~min}$ in a nitrogen atmosphere using a range of algae slurry concentrations between $15 \%$ and $30 \%$ by weight (Figure 4 ). These results show that the solid concentration of algae slurry may have had a minor effect upon the bio-crude yield (ranging between $\sim 28.9 \%$ and $33.6 \%$ ) and HHV $\left(26.5-29.8 \mathrm{MJ} \cdot \mathrm{kg}^{-1}\right.$ ) with the highest yields and HHV observed at $25 \%$ biomass concentration. However, the slurry concentration did have a significant effect 
upon chemical speciation (see Section 3.4). A similar trend for bio-crude and the water soluble fraction was reported by Jena et al. [23]. The fact that bio-crude yield peaked at the $25 \%$ slurry concentration suggests that the substrate was limiting at lower concentrations and that $\mathrm{H}^{+}$and $\mathrm{OH}^{-}$ions responsible for liquefaction become limiting at higher concentrations [23]. The presence of active hydrogen formed from the water under HTL conditions stabilizes the biomass liquefaction intermediates. This prevents formation of more new compounds that do not decompose easily, producing a higher yield of bio-crude [42]. The yield of the gas + aqueous fraction ranged between $51.1 \%$ and $60.6 \%$ over the slurry solid concentration range tested and the lowest yield $51.1 \%$ was observed at $25 \%$ solid concentration which corresponded with the highest bio-crude yields. Solid residues increased from $10.5 \%$ to $17.1 \%$ with slurry concentration due to the increase of solid mass fraction in the slurry. This corresponded with the report of Jena et al. [23] where solid residues had a small increase (5.4-7\%) with solids concentration in range from $10 \%$ to $50 \%$ [23].

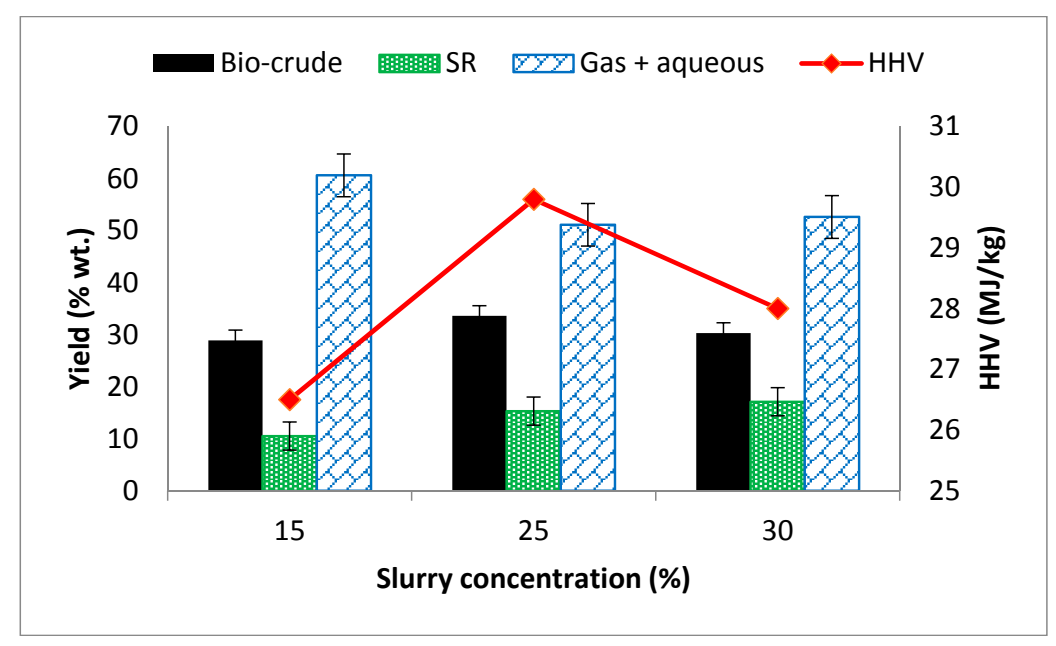

Figure 4. Effect of slurry concentration on the recovery of bio-crude, solids and gas + aqueous components after HTL treatment $\left(350{ }^{\circ} \mathrm{C}, 60 \mathrm{~min}\right)$. Standard deviations are based on two replicates; values provided are for yield data.

\subsection{Chemical Characterisation of Bio-Crude Oil}

The chemical composition of each bio-crude oil sample was characterized by GC-MS. Due to the complex composition of the bio-crude oil only abundant compounds were evaluated based on the peak areas (defined by the percentage of the chromatographic area of the compound out if the total area). GC-MS revealed distinct amounts of chemical compounds which consisted of more than $2 \%$ of the total area within the retention time range of 3-34 min. Around 64 compounds were identified which accounted for approximately $80-90 \%$ of the total peak area from all bio-oil samples and 28 of them are listed in Tables 2 and 3. The majority of the compounds obtained were cyclic nitrogenates (e.g., pyrolle, pyrazine, piperidine) and cyclic and aromatic oxygenates (e.g., phenols, ketones) which are similar to previous studies $[18,23,31]$. These compounds are formed from carbohydrates and proteins obtained from the feedstock which undergo depolymerisations, decompositions, and reformation [43]. The minor compounds were mostly hydrocarbons and esters which may be derived from lipid content. Lipids can produce stable hydrocarbons via decarboxylation and decarbonylation reactions $[43,44]$. The tables show a comparison of the identified chemical compounds in the bio-crude oil under different reaction conditions.

Table 2 presents only the key compounds that were identified through GC-MS for both solvents. It shows the effectiveness of the $n$-hexane and dichloromethane in terms of the extraction of bio-crude oil from the water soluble fraction, independently. Dichloromethane and $n$-hexane extracted $57.1 \%$ and $40.2 \%$ of heterocyclic and aromatic compounds (mostly nitrogenated) from the water, 
respectively. Ketones were the most abundant oxygenated compounds. Neither solvent had a strong influence on aliphatic recovery rates, although a slight increase was observed with dichloromethane. Valdez et al. [34] also reported that the total yields of aliphatic compounds did not vary significantly between the polar to nonpolar solvents. They also found that dichloromethane extracted more light low molecular products such as aromatics, nitrogen-, oxygen-, and sulphur-obtaining compounds, than $n$-hexane [34].

Table 2. Major compounds of recovered bio-oils obtained from HTL $\left(350^{\circ} \mathrm{C}, 60 \mathrm{~min}, 2\right.$ bar nitrogen atmosphere) using two different extraction solvents (DCM and $n$-hexane).

\begin{tabular}{|c|c|c|c|}
\hline \multirow{2}{*}{ RT (Retention Times, min) } & \multirow{2}{*}{ Name of Compound } & \multicolumn{2}{|c|}{ Area \% } \\
\hline & & DCM & $n$-Hexane \\
\hline 4.5 & 4-hydroxy-4-methyl-2-pentanone & 5.03 & - \\
\hline 4.82 & Ethylbenzene & 8.86 & 3.38 \\
\hline 4.98 & 1,4-dimethyl benzene & 11.99 & 6.34 \\
\hline 5.44 & 1,3-dimethyl benzene & 3.44 & 5.12 \\
\hline 5.82 & 2,5-dimethyl pyrazine & 4.09 & - \\
\hline 6.91 & 2,6-dimethyl-4-heptanone & - & 4.74 \\
\hline 7.54 & Trimethyl pyrazine & 2.76 & 4.3 \\
\hline 7.79 & 2,3,5-trimethyl-1H-pyrrole & - & 3.06 \\
\hline 8.18 & 2,3-dimethyl-2-cyclopenten-1-one & 5.32 & 4.36 \\
\hline 8.49 & 3,7-dimethyl undecane & - & 2.82 \\
\hline 8.77 & 4-methyl phenol & 3.53 & 4.45 \\
\hline 9.06 & 1-acetate-1,2,3-propanetriol & 2.99 & 7.11 \\
\hline 9.21 & Undecane & - & 3.91 \\
\hline 9.32 & 1-ethyl-2-pyrrolidinone & 10.38 & - \\
\hline 10.08 & 2,2,5,5-tetramethyl-3-cyclopenten-1-one & - & 5.15 \\
\hline 11.42 & 1-butyl-2-pyrrolidinone & 4.25 & 2.72 \\
\hline 12.93 & 1-pentyl piperidine & 3.78 & 4.84 \\
\hline 13.49 & 2-methyl-3-hydroxy-2,4,4-trimethylpentyl ester, propanoic acid & - & 5.11 \\
\hline 24.91 & Di(2-propylpentyl) ester, phthalic acid & 10.78 & - \\
\hline Total & 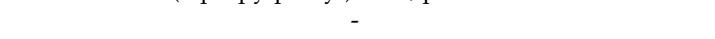 & 77.2 & 67.41 \\
\hline
\end{tabular}

-, chemical compounds either not detected or peak area less than $2 \%$.

Table 3 presents the variation of key chemical compounds from the bio-crude oil samples produced with a microalgae mass fraction in the feed ranging from $15-30 \%$ under various temperatures (280-350 ${ }^{\circ} \mathrm{C}$ ). The main compounds include: nitrogenated compounds (pyrolle, pyrazine, piperidine); oxygenated compounds (phenols, ketones, esters); aliphatics (alkanes, alkenes); and aromatics (benzene).

Table 3. Major compounds of recovered bio-oils obtained from HTL under various solid concentrations and temperature using (DCM).

\begin{tabular}{|c|c|c|c|c|c|c|c|}
\hline \multirow{3}{*}{ RT (min) } & \multirow{3}{*}{ Name of Compound } & \multicolumn{6}{|c|}{ Area $(\%)$} \\
\hline & & \multicolumn{3}{|c|}{$\begin{array}{l}\text { Slurry Concentration at } \\
\text { Fixed } 350^{\circ} \mathrm{C} \text { Temperature }\end{array}$} & \multicolumn{3}{|c|}{$\begin{array}{c}\text { Temperature at Fixed } 25 \% \\
\text { Slurry Concentration }\end{array}$} \\
\hline & & $15 \%$ & $25 \%$ & $30 \%$ & $280^{\circ} \mathrm{C}$ & $300^{\circ} \mathrm{C}$ & $350^{\circ} \mathrm{C}$ \\
\hline 4.01 & 2-methyl pyrimidine & 3.92 & - & 4.05 & 4.94 & 8.18 & - \\
\hline 4.41 & 4-hydroxy-4-methyl-2-pentanone & - & 5.03 & - & 23.8 & 4.15 & 4.03 \\
\hline 4.82 & Ethylbenzene & 0.68 & 8.86 & - & 1.34 & 1.75 & 8.86 \\
\hline 4.97 & 1,4-dimethyl benzene & - & 11.9 & - & 2.48 & 2.77 & 11.3 \\
\hline 5.67 & 2-methyl-2-cyclopenten-1-one & 4.71 & - & 2.72 & 9.19 & 10.0 & - \\
\hline 5.79 & 2,5-dimethyl pyrazine & 4.84 & 4.09 & 3.53 & 12.1 & 12.4 & 4.09 \\
\hline 6.8 & 3-methyl-2-cyclopenten-1-one & 6.66 & 4.86 & 2.31 & 2.7 & 6.0 & 4.5 \\
\hline 7.1 & Phenol & 3.24 & 3.33 & 2.16 & - & 2.43 & 3.32 \\
\hline 8.15 & 2,3-dimethyl-2-cyclopenten-1-one & 12.8 & 12.0 & 5.32 & 2.29 & 5.73 & 6.05 \\
\hline 9.03 & 1-acetate-1,2,3-Propanetriol & 4.72 & 5.09 & 5.63 & 2.58 & 4.22 & 5.19 \\
\hline 9.27 & Undecane & 9.20 & 11.1 & 12.6 & 2.49 & 5.9 & 8.99 \\
\hline 9.94 & 1,3-diethyl-3-methyl-2,5-pyrrolidinedione & 2.27 & 2.5 & 2.72 & - & 2.48 & 2.51 \\
\hline 10.69 & 1-propyl-2-pyrrolidinone & 3.04 & 2.32 & 3.48 & - & - & 2.30 \\
\hline 11.39 & 1-butyl-2-pyrrolidinone & 3.3 & 4.25 & 3.16 & - & - & 4.20 \\
\hline 24.91 & Di(2-propylpentyl) ester, phthalic acid & - & 10.7 & 8.25 & - & - & 10.7 \\
\hline
\end{tabular}

-, chemical compounds either not detected or peak area less than $2 \%$. 
As shown in Table 3, cyclic oxygenated compounds (mostly ketones such as 2,3-dimethyl-2cyclopenten-1-one), are slightly decreasing with increasing solids concentration. This was in contrast to the aliphatic components, such as undecane, which increased with the solid concentration. Cyclic nitrogenated and oxygenated compounds including 1-butyl-2-pyrrolidinone, 1,3-diethyl-3-methyl2,5-pyrrolidinedione, and 1-propyl-2-pyrrolidinone were the most abundant in each sample. In the low temperature reaction at $280{ }^{\circ} \mathrm{C}$, bio-crude oil had the highest amount of oxygenated compounds mostly aliphatic, prevalent ketones, including 4-hydroxy-4-methyl-2-pentanone, 2-methyl-2-cyclopenten-1-one, and 2,3-dimethyl-2-cyclopenten-1-one. Abundance of hydrocarbons and aromatics were the lowest for the bio-crude oil at $280{ }^{\circ} \mathrm{C}$ but had the highest percentages at $350^{\circ} \mathrm{C}$. The number of identified nitrogenated compounds such as pyrazine, 2-methyl-2,5-dimethyl, pyrimidine, trimethyl and pyrazine, initially, increased with temperature and reached the maximum at $300{ }^{\circ} \mathrm{C}$ after which it decreased. Jena et al. obtained similar results from bio-crude oil comparing five different temperatures [23]. Esters such as Di(2-propylpentyl) ester, phthalic acid, 15-methyl ethyl ester, and heptadecanoic acid, were observed only at the highest temperature. The detailed analysis shows the strong dependency of chemical compounds on process condition.

\subsection{Effect of Temperature and Concentration on Chemical and Physical Properties}

Both the chemical and physical properties of biofuels are important to define fuel quality in terms of combustibility, density, energy content, and lubricity. These fuel properties vary with chemical composition and influence engine performance and emission results [20,45-49]. It was observed that the chemical components and compositions of the bio-crude varied with the process conditions (Tables 2 and 3) which subsequently affected the fuel's physical properties. Table 4 shows the effect of temperature and concentration on ultimate analysis and higher heating value (HHV) of the microalgae bio-crude. The chemical and physical properties of microalgae HTL bio-crude are shown in Table 5 and compared with FAME microalgae biofuel and mineral diesel.

Table 4. Ultimate analysis and higher heating value (HHV) of the microalgae bio-crude.

\begin{tabular}{|c|c|c|c|c|c|c|}
\hline \multirow[t]{2}{*}{ Component (wt. \%) } & \multicolumn{3}{|c|}{$\begin{array}{l}25 \% \text { Slurry Concentration at } \\
\text { Different Temperature }\end{array}$} & \multicolumn{3}{|c|}{$\begin{array}{c}350^{\circ} \mathrm{C} \text { Temperature at Slurry } \\
\text { Concentration }\end{array}$} \\
\hline & $280^{\circ} \mathrm{C}$ & $300^{\circ} \mathrm{C}$ & $350^{\circ} \mathrm{C}$ & $15 \%$ & $25 \%$ & $30 \%$ \\
\hline $\mathrm{C}$ & 68.1 & 70.4 & 75.6 & 74.1 & 75.6 & 73.7 \\
\hline $\mathrm{H}$ & 9.3 & 8.9 & 10.1 & 9.7 & 10.1 & 9.8 \\
\hline $\mathrm{O}$ & 15.7 & 12.1 & 10.3 & 11.2 & 10.3 & 10.8 \\
\hline $\mathrm{N}$ & 6.9 & 8.6 & 4.0 & 5.0 & 4.0 & 5.7 \\
\hline $\mathrm{H}: \mathrm{C}$ & 0.14 & 0.13 & 0.13 & 0.13 & 0.13 & 0.13 \\
\hline $\mathrm{O}: \mathrm{C}$ & 0.23 & 0.17 & 0.14 & 0.15 & 0.14 & 0.15 \\
\hline $\mathrm{N}: \mathrm{C}$ & 0.10 & 0.12 & 0.05 & 0.07 & 0.05 & 0.08 \\
\hline $\mathrm{HHV}$ (Cal.), MJ.kg ${ }^{-1}$ & 33.5 & 34.3 & 37.4 & 36.4 & 37.5 & 36.5 \\
\hline HHV(Meas.), MJ $\cdot \mathrm{kg}^{-1}$ & - & 26.1 & 29.8 & 26.5 & 29.8 & 28.0 \\
\hline
\end{tabular}

\subsubsection{Bio-Crude Chemical Composition}

The extracted bio-crude contained a range of complex hydrocarbon groups including aliphatics, aromatics, as well as nitrogenated and oxygenated compounds. Hydrocarbons mostly contained either oxygen or nitrogen in the $\mathrm{C}-\mathrm{H}$ chain. Table 4 shows the elemental composition of the bio-crude obtained at different temperatures with $25 \%$ slurry concentrations and for different slurry concentration at $350{ }^{\circ} \mathrm{C}$. The elemental analysis showed that the mass percentage of oxygen decreased from $16 \%$ to $10 \%$ with increasing temperature of the experiment for $25 \%$ slurry. In contrast, the hydrogen percentage was relatively stable: within $8.93-10.14 \%$ over the experimental range. The differences in chemical composition and molecular structure (e.g., C, H, and O composition, straight chain, cyclic, and heterocyclic compounds) affect the physical properties of the bio-crude oil including 
higher heating value, density, viscosity, cetane number, and surface tension; important parameters for internal combustion (IC) engines. The slow heat-up and cooling down time can potentially lead to polymerisation and secondary reactions. It is expected that the engine performance and exhaust emissions would be different compared to FAME biodiesel. For instance, the oxygen creates a permanent dipole moment which results in stronger hydrogen bonding and oxygenated fuels with increased molecular affinity. Consequently, compressibility is decreased because the free space between the molecules is similar. A follow-on effect is an increase in $\mathrm{NO}_{x}$ [45]. Nabi et al. [50] has also shown $\mathrm{NO}_{x}$ emissions and adiabatic flame temperature present a linear decrease with increasing oxygen content.

$\mathrm{O}: \mathrm{C}, \mathrm{N}: \mathrm{C}$, and $\mathrm{H}: \mathrm{C}$ significantly affect fuel quality and emissions, and so the temperature variation and slurry concentration effect on bio-crude were compared with diesel and FAME biodiesel standards in the Van Krevelen diagram (Figure 5) [51,52]. It is important to note that the lowest N:C and O:C were found at the same conditions which gave maximum bio-crude yield and $\mathrm{HHV}$ (i.e., $350{ }^{\circ} \mathrm{C}$ and $25 \%$ slurry concentration; for this range, the author's viewed lower O:C to be more beneficial). Figure 5 shows that $\mathrm{O}: \mathrm{C}$ changes with respect to $\mathrm{N}: \mathrm{C}$ ratio, and $\mathrm{H}: \mathrm{C}$ is almost constant; thus, $\mathrm{N}: \mathrm{C}$ and $\mathrm{O}: \mathrm{C}$ varied more than $\mathrm{H}: \mathrm{C}$. The HHV is the highest at $350{ }^{\circ} \mathrm{C}$ due to the low $\mathrm{O}: \mathrm{C}$ and relatively good $\mathrm{H}: \mathrm{C}$. $\mathrm{N}: \mathrm{C}$ also sharply reduced at high temperature. The bio-crude oils were more similar to FAME biodiesel than fossil fuel diesel in terms of $\mathrm{H}: \mathrm{C}$ while the nitrogen concentration was much higher than diesel and biodiesel standards due to the high amount of proteins in the raw feedstock. We note that if $n$-hexane had been used for the extraction rather than DCM the polarity of the bio-crude would fall and, consequently, the point would shift to the left on Figure 5 due to the lower oxygen content.

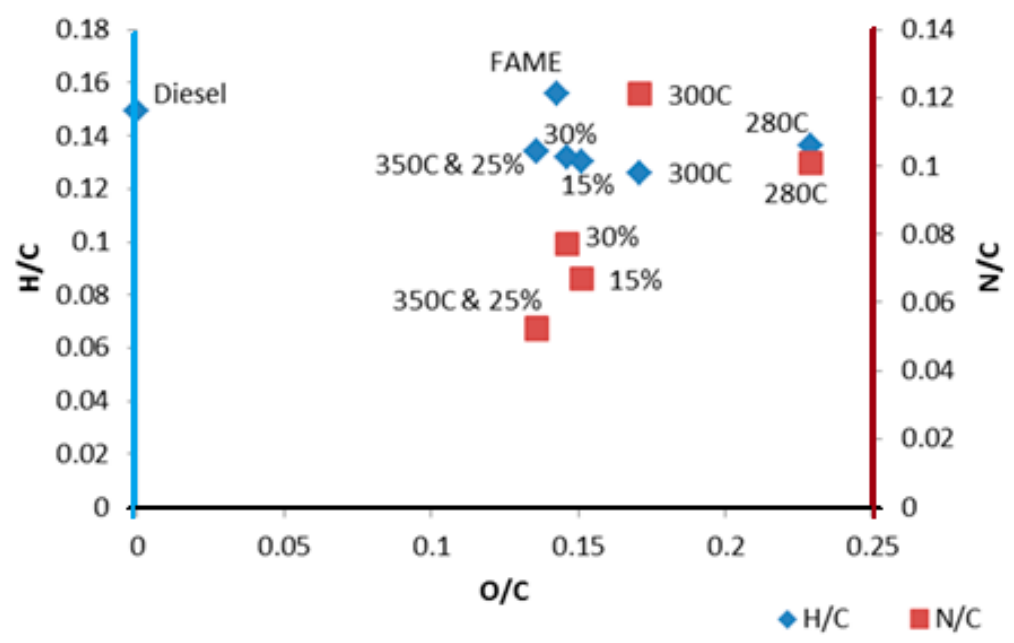

Figure 5. Van Krevelen diagram of bio-crudes gained for different temperatures $\left(280^{\circ} \mathrm{C}, 300{ }^{\circ} \mathrm{C}\right.$, and $\left.350{ }^{\circ} \mathrm{C}\right)$ and slurry concentration $(15 \%, 20 \%$ and $30 \%)$ in comparison with diesel and FAME biodiesel standards [53].

The separated bio-crude oil samples had a dark colour, high viscosity, and an acrid smoky odour. Chemical and physical properties were analysed for the best bio-crude produced at $350{ }^{\circ} \mathrm{C}$, and $25 \%$ initial solids concentration and compared with various types of fuel standards (Table 5). 
Table 5. Comparison of chemical and physical properties of bio-crude produced at $350{ }^{\circ} \mathrm{C}$ and $25 \%$ solids with trans-esterified microalgae biodiesel, diesel, biodiesel, and marine fuels standards. *: at $20^{\circ} \mathrm{C}$.

\begin{tabular}{|c|c|c|c|c|c|}
\hline Name of the Properties & $\begin{array}{c}\text { HTL Scenedesmus } \\
\text { sp. Biocrude Oil }\end{array}$ & $\begin{array}{c}\text { FAME } \\
\text { Crypthecodinium } \\
\text { cohnii Biodiesel [52] }\end{array}$ & $\begin{array}{c}\text { Biodiesel } \\
\text { Standards EN } \\
14214\end{array}$ & $\begin{array}{l}\text { Petroleum } \\
\text { Diesel }\end{array}$ & $\begin{array}{c}\text { Marine } \\
\text { Fuels ISO } \\
8217\end{array}$ \\
\hline Kinematic viscosity@40 ${ }^{\circ} \mathrm{C}\left(\mathrm{mm}^{2} \cdot \mathrm{s}^{-1}\right)$ & $70.7-73.8$ & 5.06 & $3.5-5$ & 2.64 & $1.4-11.0$ \\
\hline Density @15 ${ }^{\circ} \mathrm{C}\left(\mathrm{kg} \cdot \mathrm{L}^{-1}\right)$ & 0.97 * & 0.91 & $0.86-0.9$ & 0.84 & $0.96-0.99$ \\
\hline $\mathrm{HHV}\left(\mathrm{MJ} \cdot \mathrm{kg}^{-1}\right)$ & 29.7 & 39.8 & - & 44 & $44-45$ \\
\hline Oxygen content (wt. \%) & 10.3 & 10.4 & - & 0 & - \\
\hline Hydrogen Content (wt. \%) & 10.1 & 11.1 & - & 13.8 & - \\
\hline Carbon Content (wt. \%) & 75.5 & 78.4 & - & 86.1 & - \\
\hline Nitrogen Content (wt. \%) & 3.97 & 0 & - & 0 & - \\
\hline
\end{tabular}

\subsubsection{Viscosity}

Under the best conditions, the viscosity of the HTL microalgae bio-fuel was closer to conventional diesel and biodiesel than FAME from microalgae and varied with chemical composition, possibly due to the varying degree of chemical saturation [54]. The variation of bio-crude compositions influenced the intermolecular forces. The variation in viscosity can potentially affect injection timing, spray, atomization, and combustion compared to microalgae FAME [28]. There is a possibility to use bio-crude in a heavy-duty diesel engine or a marine ship engine with minimal upgrading.

\subsubsection{Density}

The fuel density affects the mass of fuel injected because fuel injection systems in modern diesel engines measure the fuel on a volume basis [45]. At best conditions, the density of the HTL microalgae bio-crude was $13 \%$ higher than conventional diesel fuel and not comparable with any fuel standards in Table 5. The increased density of the HTL microalgae bio-crude might be due to it containing many aromatic hydrocarbons and cyclic chemicals as well as an amount of high molecular weight compounds that are beyond detection in GC-MS. However, the density value $\left(0.97 \mathrm{~kg} \cdot \mathrm{L}^{-1}\right)$ is comparable to the marine residual fuel standard ISO 8217:2012 $\left(0.96-0.99 \mathrm{~kg} \cdot \mathrm{m}^{-3}\right)$.

\subsubsection{Higher Heating Value}

Among the fuels, the HHV of microalgae bio-crude had the lowest value $29.8 \mathrm{MJ} \cdot \mathrm{kg}^{-1}$ (best $\mathrm{H}: \mathrm{C}$ ) [55]. Enrichment in double bonds generally results in lower than expected levels of heats of combustion due to strong intra-molecular bonding [56]. The vapour heat capacity and thermal conductivity relates to the heating value of the fuel. These affect droplet-surrounding heat transfer, temperature distribution and the mass air fuel ratio that will reduce combustion performance [57].

\subsection{Comparison with Previous Studies}

The findings of this study are compared with previous workers in Table 6 where most researchers worked with very small batch reactors $(<100 \mathrm{~mL})$ although there has been a few studies with larger continuous reactors (typically $\sim 1000 \mathrm{~mL}$ ). The vast majority of HTL studies report physical properties, HHV in particular, derived from correlations which use elemental analysis results for gaseous, liquid, coal and biomass materials [36,39]. Our calculated values for HHV are similar to that reported elsewhere, but we also report a much lower measured value which was also reported by Li [58], although despite the different oxygen content.

The density and viscosity of the bio-crude are not widely reported (Table 6). The bio-crude viscosity was significantly closer to regular diesel and biodiesel standards than transesterified (FAME) microalgae biodiesel. Under optimised conditions, HTL bio-crude's high density $\left(0.97-1.04 \mathrm{~kg} \cdot \mathrm{L}^{-1}\right)$ and its high viscosity $\left(70.7-73.8 \mathrm{~mm}^{2} \cdot \mathrm{s}^{-1}\right)$ had enough similarity to marine heavy fuels that it could be immediately used without further processing, although the measured higher heating value, HHV, was lower $\left(29.8 \mathrm{MJ} \cdot \mathrm{kg}^{-1}\right)$. 
Table 6. Comparison of results from this study with literature.

\begin{tabular}{|c|c|c|c|c|c|c|c|c|c|c|c|c|c|c|}
\hline \multirow{3}{*}{ HTL Bio-Crude } & \multirow{3}{*}{ Reactor Type } & \multirow{3}{*}{$\begin{array}{l}\text { Reactor } \\
\text { Volume } \\
(\mathrm{mL})\end{array}$} & \multicolumn{2}{|c|}{ Operating Conditions } & \multirow{3}{*}{$\begin{array}{l}\text { Yield } \\
\text { wt. \% }\end{array}$} & \multicolumn{8}{|c|}{ Physicochemical Properties } & \multirow{3}{*}{ References } \\
\hline & & & \multirow{2}{*}{$\begin{array}{c}\text { Temperature } \\
\left({ }^{\circ} \mathrm{C}\right)\end{array}$} & \multirow{2}{*}{$\begin{array}{l}\text { Time } \\
(\mathrm{min})\end{array}$} & & \multicolumn{4}{|c|}{ Chemical Composition \% } & \multicolumn{2}{|c|}{ HHV (MJ/kg) } & \multirow{2}{*}{$\begin{array}{c}\text { Kinematic } \\
\text { Viscosity }\left(\mathrm{mm}^{2} / \mathrm{s}\right)\end{array}$} & \multirow{2}{*}{$\begin{array}{c}\text { Density } \\
(\mathrm{kg} / \mathrm{L})\end{array}$} & \\
\hline & & & & & & C & $\mathbf{H}$ & $\mathbf{N}$ & $\mathrm{O}$ & Calculated & Measured & & & \\
\hline \multirow{2}{*}{ Scenedesmus sp. } & \multirow{9}{*}{ Batch reactor } & 1800 & 350 & 60 & 33.6 & 75.6 & 10.1 & 3.97 & 10.3 & 37.4 & 29.8 & $70.7-73.8$ & 0.97 & Current study \\
\hline & & 500 & 300 & 30 & 45 & 72.6 & 9.0 & 6.5 & 10.5 & 35.5 & - & - & - & [59] \\
\hline Enteromorpha prolifera & & 25 & 300 & 30 & 23 & 64.5 & 7.7 & 5.4 & 22.4 & 30.8 & - & - & - & [60] \\
\hline Lemna sp. & & 25 & 350 & 30 & 17.5 & 72.1 & 7.8 & 4.6 & 15.5 & 32.8 & - & - & - & [61] \\
\hline Laminaria saccharina & & 75 & 350 & 15 & 19.3 & 82.0 & 7.1 & 4.9 & 6.0 & 37.4 & - & - & - & [27] \\
\hline Chlorella pyrenoidosa & & 17.2 & 350 & 60 & 41 & 75.1 & 9.9 & 7.3 & 7.7 & 38.1 & - & - & - & [62] \\
\hline Nannochloropsis sp. & & 35 & 350 & 60 & 43 & 76.0 & 10.3 & 3.9 & 9.0 & 39 & - & - & - & [32] \\
\hline Enteromorpha prolifera & & 25 & 370 & 40 & 31.7 & 77.9 & 9.6 & 5.6 & 6.9 & 39.4 & - & - & - & [10] \\
\hline Sargassum patens C. Agardh & & 1000 & 340 & 10 & 32.1 & 64.6 & 7.4 & 2.5 & 25.5 & - & 27.1 & - & - & [58] \\
\hline \multirow{2}{*}{$\begin{array}{l}\text { Saccharina sp. } \\
\text { NB238 }\end{array}$} & \multirow{2}{*}{$\begin{array}{l}\text { Continuous-flow } \\
\text { reactor }\end{array}$} & 1000 & 340 & 87 & 58.8 & 79.4 & 8.0 & 4.1 & 8.5 & 37.5 & - & - & - & [63] \\
\hline & & 1000 & 350 & - & 38 & 78.6 & 10.4 & 4.2 & 5.3 & - & - & - & - & [64] \\
\hline
\end{tabular}




\section{Conclusions}

This paper studied the relationship of HTL operating conditions (reaction temperature and slurry concentration) on the chemical pomposities and physical and chemical properties of the microalgae bio-crude. Physical properties were able to be measured experimentally because of the larger scale of the reactor rather than being derived using correlations based on elemental analysis. We note a significant difference in the values for calculated and measured values, which is consistent with the literature. The highest bio-crude oil yield $(33.6 \%)$ was produced at $350{ }^{\circ} \mathrm{C}$ and at $25 \%$ solids concentration. The aliphatic, aromatic, nitrogen containing hetero-cyclic, oxygenated compounds were the major group of components of HTL microalgae bio-crude. These conditions also produced the lowest O:C and N:C. The bio-crude had higher density and lower HHV than diesel and biodiesel and was closer in character to heavy fuel oil where it could be used directly. Future work will focus on further improving chemical and physical properties, such as $\mathrm{HHV}$, density, and decreasing $\mathrm{N}$ and $\mathrm{O}$ percentages, via catalytic upgrading, or via reactions in situ, followed by engine testing.

Acknowledgments: This work was financially supported by the QUT Early Career Academic Recruitment and Development program and by a Ph.D. scholarship from the QUT School of Chemistry, Physics, and Mechanical Engineering. The authors thank to the QUT Central Analytical Research Facility for their assistance.

Author Contributions: All authors contributed to this publication and have read and approved the final manuscript.

Conflicts of Interest: The authors declare no conflict of interest.

\section{References}

1. Islam, M.; Magnusson, M.; Brown, R.; Ayoko, G.; Nabi, M.; Heimann, K. Microalgal species selection for biodiesel production based on fuel properties derived from fatty acid profiles. Energies 2013, 6, 5676-5702. [CrossRef]

2. Eboibi, B.E.-O.; Lewis, D.M.; Ashman, P.J.; Chinnasamy, S. Hydrothermal liquefaction of microalgae for biocrude production: Improving the biocrude properties with vacuum distillation. Bioresour. Technol. 2014, 174, 212-221. [CrossRef] [PubMed]

3. Azad, A.K.; Rasul, M.G.; Khan, M.M.K.; Sharma, S.C.; Hazrat, M.A. Prospect of biofuels as an alternative transport fuel in Australia. Renew. Sustain. Energy Rev. 2015, 43, 331-351. [CrossRef]

4. Oncel, S.S. Microalgae for a macroenergy world. Renew. Sustain. Energy Rev. 2013, 26, 241-264. [CrossRef]

5. D’Ippolito, G.; Sardo, A.; Paris, D.; Vella, F.M.; Adelfi, M.G.; Botte, P.; Gallo, C.; Fontana, A. Potential of lipid metabolism in marine diatoms for biofuel production. Biotechnol. Biofuels 2015, 8, 28. [CrossRef] [PubMed]

6. Kosinkova, J.; Doshi, A.; Maire, J.; Ristovski, Z.; Brown, R.; Rainey, T.J. Measuring the regional availability of biomass for biofuels and the potential for microalgae. Renew. Sustain. Energy Rev. 2015, 49, 1271-1285. [CrossRef]

7. Subramanian, S.; Barry, A.N.; Pieris, S.; Sayre, R.T. Comparative energetics and kinetics of autotrophic lipid and starch metabolism in chlorophytic microalgae: Implications for biomass and biofuel production. Biotechnol. Biofuels 2013, 6. [CrossRef] [PubMed]

8. Guccione, A.; Biondi, N.; Sampietro, G.; Rodolfi, L.; Bassi, N.; Tredici, M.R. Chlorella for protein and biofuels: From strain selection to outdoor cultivation in a Green Wall Panel photobioreactor. Biotechnol. Biofuels 2014, 7, 84. [CrossRef] [PubMed]

9. Naveena, B.; Armshaw, P.; Tony Pembroke, J. Ultrasonic intensification as a tool for enhanced microbial biofuel yields. Biotechnol. Biofuels 2015, 8. [CrossRef] [PubMed]

10. Xu, Y.-P.; Duan, P.-G.; Wang, F. Hydrothermal processing of macroalgae for producing crude bio-oil. Fuel Process. Technol. 2015, 130, 268-274. [CrossRef]

11. Bennion, E.P.; Ginosar, D.M.; Moses, J.; Agblevor, F.; Quinn, J.C. Lifecycle assessment of microalgae to biofuel: Comparison of thermochemical processing pathways. Appl. Energy 2015, 154, 1062-1071. [CrossRef]

12. López Barreiro, D.; Prins, W.; Ronsse, F.; Brilman, W. Hydrothermal liquefaction (HTL) of microalgae for biofuel production: State of the art review and future prospects. Biomass Bioenergy 2013, 53, 113-127. [CrossRef] 
13. Peng, X.; Ma, X.; Lin, Y.; Wang, X.; Zhang, X.; Yang, C. Effect of process parameters on solvolysis liquefaction of Chlorella pyrenoidosa in ethanol-water system and energy evaluation. Energy Convers. Manag. 2016, 117, 43-63. [CrossRef]

14. Amin, S. Review on biofuel oil and gas production processes from microalgae. Energy Convers. Manag. 2009, 50, 1834-1840. [CrossRef]

15. Srirangan, K.; Akawi, L.; Moo-Young, M.; Chou, C.P. Towards sustainable production of clean energy carriers from biomass resources. Appl. Energy 2012, 100, 172-186. [CrossRef]

16. Zhang, L.; Xu, C.; Champagne, P. Overview of recent advances in thermo-chemical conversion of biomass. Energy Convers. Manag. 2010, 51, 969-982. [CrossRef]

17. Dote, Y.; Sawayama, S.; Inoue, S.; Minowa, T.; Yokoyama, S.-Y. Recovery of liquid fuel from hydrocarbon-rich microalgae by thermochemical liquefaction. Fuel 1994, 73, 1855-1857. [CrossRef]

18. Vardon, D.R.; Sharma, B.K.; Blazina, G.V.; Rajagopalan, K.; Strathmann, T.J. Thermochemical conversion of raw and defatted algal biomass via hydrothermal liquefaction and slow pyrolysis. Bioresour. Technol. 2012, 109, 178-187. [CrossRef] [PubMed]

19. Mandal, S.; Mallick, N. Microalga Scenedesmus obliquus as a potential source for biodiesel production. Appl. Microbiol. Biotechnol. 2009, 84, 281-291. [CrossRef] [PubMed]

20. Rahman, M.M.; Pourkhesalian, A.M.; Jahirul, M.I.; Stevanovic, S.; Pham, P.X.; Wang, H.; Masri, A.R.; Brown, R.J.; Ristovski, Z.D. Particle emissions from biodiesels with different physical properties and chemical composition. Fuel 2014, 134, 201-208. [CrossRef]

21. Demirbas, A. Progress and recent trends in biodiesel fuels. Energy Convers. Manag. 2009, 50, 14-34. [CrossRef]

22. Hossain, F.M.; Rainey, T.J.; Ristovski, Z.; Brown, R.J. Performance and exhaust emissions of diesel engines using microalgae FAME and the prospects for microalgae HTL biocrude. Renew. Sustain. Energy Rev. 2017, submitted.

23. Jena, U.; Das, K.C.; Kastner, J.R. Effect of operating conditions of thermochemical liquefaction on biocrude production from Spirulina platensis. Bioresour. Technol. 2011, 102, 6221-6229. [CrossRef] [PubMed]

24. $\mathrm{Xu}, \mathrm{D}$.; Savage, P.E. Characterization of biocrudes recovered with and without solvent after hydrothermal liquefaction of algae. Algal Res. 2014, 6, 1-7. [CrossRef]

25. Eboibi, B.E.; Lewis, D.M.; Ashman, P.J.; Chinnasamy, S. Effect of operating conditions on yield and quality of biocrude during hydrothermal liquefaction of halophytic microalga Tetraselmis sp. Bioresour. Technol. 2014, 170, 20-29. [CrossRef] [PubMed]

26. Zheng, Z.; Tang, X.; Asa-Awuku, A.; Jung, H.S. Characterization of a method for aerosol generation from heavy fuel oil (HFO) as an alternative to emissions from ship diesel engines. J. Aerosol Sci. 2010, 41, 1143-1151. [CrossRef]

27. Anastasakis, K.; Ross, A.B. Hydrothermal liquefaction of the brown macro-alga Laminaria Saccharina: Effect of reaction conditions on product distribution and composition. Bioresour. Technol. 2011, 102, 4876-4883. [CrossRef] [PubMed]

28. Ramirez, J.A.; Brown, R.J.; Rainey, T.J. A review of hydrothermal liquefaction bio-crude properties and prospects for upgrading to transportation fuels. Energies 2015, 8, 6765-6794. [CrossRef]

29. Smook, G. Handbook for Pulp and Paper Technologists; TAPPI Press: Quebec, QC, Canada, 1982; Chapter 8; p. 76.

30. Biller, P.; Riley, R.; Ross, A. Catalytic hydrothermal processing of microalgae: Decomposition and upgrading of lipids. Bioresour. Technol. 2011, 102, 4841-4848. [CrossRef] [PubMed]

31. Biller, P.; Ross, A. Potential yields and properties of oil from the hydrothermal liquefaction of microalgae with different biochemical content. Bioresour. Technol. 2011, 102, 215-225. [CrossRef] [PubMed]

32. Brown, T.M.; Duan, P.; Savage, P.E. Hydrothermal liquefaction and gasification of Nannochloropsis sp. Energy Fuels 2010, 24, 3639-3646. [CrossRef]

33. Matsui, T.-O.; Nishihara, A.; Ueda, C.; Ohtsuki, M.; Ikenaga, N.-O.; Suzuki, T. Liquefaction of micro-algae with iron catalyst. Fuel 1997, 76, 1043-1048. [CrossRef]

34. Valdez, P.J.; Dickinson, J.G.; Savage, P.E. Characterization of product fractions from hydrothermal liquefaction of Nannochloropsis sp. and the influence of solvents. Energy Fuels 2011, 25, 3235-3243. [CrossRef]

35. Jakob, G.; Wolf, J.; Bui, T.V.; Posten, C.; Kruse, O.; Stephens, E.; Ross, I.; Hankamer, B. Surveying a diverse pool of microalgae as a bioresource for future biotechnological applications. J. Phylogenet. Evol. Biol. 2013, 4, 1000153.1-1000153.8. [CrossRef] 
36. Demirbas, A. Calculation of higher heating values of biomass fuels. Fuel 1997, 76, 431-434. [CrossRef]

37. Friedl, A.; Padouvas, E.; Rotter, H.; Varmuza, K. Prediction of heating values of biomass fuel from elemental composition. Anal. Chim. Acta 2005, 544, 191-198. [CrossRef]

38. Yu, G.; Zhang, Y.; Schideman, L.; Funk, T.L.; Wang, Z. Hydrothermal liquefaction of low lipid content microalgae into bio-crude oil. Am. Soc. Agric. Eng. 2011, 54, 239-246.

39. Boie, W. Fuel technology calculations. Energietechnik 1953, 3, 309-316.

40. Xu, C.; Etcheverry, T. Hydro-liquefaction of woody biomass in sub-and super-critical ethanol with iron-based catalysts. Fuel 2008, 87, 335-345. [CrossRef]

41. Garcia Alba, L.; Torri, C.; Samorì, C.; van der Spek, J.; Fabbri, D.; Kersten, S.R.; Brilman, D.W. Hydrothermal treatment (HTT) of microalgae: Evaluation of the process as conversion method in an algae biorefinery concept. Energy Fuels 2011, 26, 642-657. [CrossRef]

42. Huang, H.; Yuan, X.; Zeng, G.; Wang, J.; Li, H.; Zhou, C.; Pei, X.; You, Q.; Chen, L. Thermochemical liquefaction characteristics of microalgae in sub-and supercritical ethanol. Fuel Process. Technol. 2011, 92, 147-153. [CrossRef]

43. Toor, S.S.; Rosendahl, L.; Rudolf, A. Hydrothermal liquefaction of biomass: A review of subcritical water technologies. Energy 2011, 36, 2328-2342. [CrossRef]

44. Peterson, A.A.; Vogel, F.; Lachance, R.P.; Fröling, M.; Antal, M.J., Jr.; Tester, J.W. Thermochemical biofuel production in hydrothermal media: A review of sub-and supercritical water technologies. Energy Environ. Sci. 2008, 1, 32-65. [CrossRef]

45. Varatharajan, K.; Cheralathan, M. Influence of fuel properties and composition on $\mathrm{NO}_{x}$ emissions from biodiesel powered diesel engines: A review. Renew. Sustain. Energy Rev. 2012, 16, 3702-3710. [CrossRef]

46. Giakoumis, E.G. A statistical investigation of biodiesel physical and chemical properties, and their correlation with the degree of unsaturation. Renew. Energy 2013, 50, 858-878. [CrossRef]

47. Pandey, R.K.; Rehman, A.; Sarviya, R.M. Impact of alternative fuel properties on fuel spray behavior and atomization. Renew. Sustain. Energy Rev. 2012, 16, 1762-1778. [CrossRef]

48. Kegl, B. Effects of biodiesel on emissions of a bus diesel engine. Bioresour Technol. 2008, 99, 863-873. [CrossRef] [PubMed]

49. Vajda, B.; Lešnik, L.; Bombek, G.; Biluš, I.; Žunič, Z.; Škerget, L.; Hočevar, M.; Širok, B.; Kegl, B. The numerical simulation of biofuels spray. Fuel 2015, 144, 71-79. [CrossRef]

50. Nabi, M.N. Theoretical investigation of engine thermal efficiency, adiabatic flame temperature, NOx emission and combustion-related parameters for different oxygenated fuels. Appl. Therm. Eng. 2010, 30, 839-844. [CrossRef]

51. Senneca, O. Kinetics of pyrolysis, combustion and gasification of three biomass fuels. Fuel Process. Technol. 2007, 88, 87-97. [CrossRef]

52. Yuliansyah, A.T.; Hirajima, T. Efficacy of Hydrothermal Treatment for Production of Solid Fuel from Oil Palm Wastes; INTECH: Rijeka, Croatia, 2012.

53. Tyson, K.S.; McCormick, R.L. Biodiesel Handling and Use Guidelines; DIANE Publishing: Collingdale, PA, USA, 2006.

54. Boelhouwer, J.; Nederbragt, G.; Verberg, G. Viscosity data of organic liquids. Appl. Sci. Res. 1951, 2, $249-268$. [CrossRef]

55. Vihar, R.; Seljak, T.; Rodman Oprešnik, S.; Katrašnik, T. Combustion characteristics of tire pyrolysis oil in turbo charged compression ignition engine. Fuel 2015, 150, 226-235. [CrossRef]

56. Lang, X.; Dalai, A.K.; Bakhshi, N.N.; Reaney, M.J.; Hertz, P. Preparation and characterization of bio-diesels from various bio-oils. Bioresour. Technol. 2001, 80, 53-62. [CrossRef]

57. Abramzon, B.; Sazhin, S. Convective vaporization of a fuel droplet with thermal radiation absorption. Fuel 2006, 85, 32-46. [CrossRef]

58. Li, D.; Chen, L.; Xu, D.; Zhang, X.; Ye, N.; Chen, F.; Chen, S. Preparation and characteristics of bio-oil from the marine brown alga Sargassum patens C. Agardh. Bioresour. Technol. 2012, 104, 737-742. [CrossRef] [PubMed]

59. Vardon, D.R. Hydrothermal Liquefaction for Energy Recovery from High-Moisture Waste Biomass. Master's Thesis, University of Illinois at Urbana Champaign, Champaign, IL, USA, 2012.

60. Zhou, D.; Zhang, L.; Zhang, S.; Fu, H.; Chen, J. Hydrothermal liquefaction of macroalgae enteromorpha prolifera to bio-oil. Energy Fuels 2010, 24, 4054-4061. [CrossRef] 
61. Duan, P.; Chang, Z.; Xu, Y.; Bai, X.; Wang, F.; Zhang, L. Hydrothermal processing of duckweed: Effect of reaction conditions on product distribution and composition. Bioresour. Technol. 2013, 135, 710-719. [CrossRef] [PubMed]

62. Duan, P.; Bai, X.; Xu, Y.; Zhang, A.; Wang, F.; Zhang, L.; Miao, J. Catalytic upgrading of crude algal oil using platinum/gamma alumina in supercritical water. Fuel 2013, 109, 225-233. [CrossRef]

63. Elliott, D.C.; Hart, T.R.; Neuenschwander, G.G.; Rotness, L.J.; Roesijadi, G.; Zacher, A.H.; Magnuson, J.K. Hydrothermal processing of macroalgal feedstocks in continuous-flow reactors. ACS Sustain. Chem. Eng. 2013, 2, 207-215. [CrossRef]

64. Elliott, D.C.; Hart, T.R.; Schmidt, A.J.; Neuenschwander, G.G.; Rotness, L.J.; Olarte, M.V.; Zacher, A.H.; Albrecht, K.O.; Hallen, R.T.; Holladay, J.E. Process development for hydrothermal liquefaction of algae feedstocks in a continuous-flow reactor. Algal Res. 2013, 2, 445-454. [CrossRef]

(C) 2017 by the authors. Licensee MDPI, Basel, Switzerland. This article is an open access article distributed under the terms and conditions of the Creative Commons Attribution (CC BY) license (http:/ / creativecommons.org/licenses/by/4.0/). 